\title{
The Role of Gonadotropin-Releasing Hormone in Cancer Cell Proliferation and Metastasis
}

\author{
Carsten Gründker* and Günter Emons \\ Department of Gynecology and Obstetrics, Georg-August-University, Göttingen, Germany
}

In several human malignant tumors of the urogenital tract, including cancers of the endometrium, ovary, urinary bladder, and prostate, it has been possible to identify expression of gonadotropin-releasing hormone $(\mathrm{GnRH})$ and its receptor as part of an autocrine system, which regulates cell proliferation. The expression of $\mathrm{GnRH}$ receptor has also been identified in breast cancers and non-reproductive cancers such as pancreatic cancers and glioblastoma. Various investigators have observed dose- and timedependent growth inhibitory effects of $\mathrm{GnRH}$ agonists in cell lines derived from these cancers. GnRH antagonists have also shown marked growth inhibitory effects on most cancer cell lines. This indicates that in the GnRH system in cancer cells, there may

OPEN ACCESS

Edited by:

Zvi Naor,

Tel Aviv University, Israel

Reviewed by:

Erik Hrabovszky,

Institute of Experimental

Medicine (MTA), Hungary

Tullio Florio,

Università di Genova, Italy

${ }^{*}$ Correspondence:

Carsten Gründker

grundker@med.uni-goettingen.de

Specialty section:

This article was submitted to

Neuroendocrine Science,

a section of the journal

Frontiers in Endocrinology

Received: 11 May 2017

Accepted: 18 July 2017

Published: 04 August 2017

Citation:

Gründker C and Emons G (2017) The

Role of Gonadotropin-Releasing

Hormone in Cancer Cell

Proliferation and Metastasis.

Front. Endocrinol. 8:187.

doi: 10.3389/fendo.2017.00187 not be a dichotomy between $\mathrm{GnRH}$ agonists and antagonists. The well-known signaling mechanisms of the $\mathrm{GnRH}$ receptor, which are present in pituitary gonadotrophs, are not involved in forwarding the antiproliferative effects of $\mathrm{GnRH}$ analogs in cancer cells. Instead, the $\mathrm{GnRH}$ receptor activates a phosphotyrosine phosphatase (PTP) and counteracts with the mitogenic signal transduction of growth factor receptors, which results in a reduction of cancer cell proliferation. The PTP activation, which is induced by $\mathrm{GnRH}$, also inhibits G-protein-coupled estrogen receptor 1 (GPER), which is a membrane-bound receptor for estrogens. GPER plays an important role in breast cancers, which do not express the estrogen receptor $\alpha(E R \alpha)$. In metastatic breast, ovarian, and endometrial cancer cells, GnRH reduces cell invasion in vitro, metastasis in vivo, and the increased expression of S100A4 and CYR61. All of these factors play important roles in epithelial-mesenchymal transition. This review will summarize the present state of knowledge about the $\mathrm{GnRH}$ receptor and its signaling in human cancers.

Keywords: gonadotropin-releasing hormone, cancer, proliferation, metastasis, signal transduction

\section{EXPRESSION OF GONADOTROPIN-RELEASING HORMONE (GnRH) AND ITS RECEPTOR IN HUMAN CANCERS}

In several earlier studies, it has been demonstrated that cancers of the breast, ovary, and endometrium have receptors for GnRH (1). Receptor-binding abilities are different between pituitary gonadotrophs and cancer cells. In cancer cells are two types of GnRH-binding sites, one with low affinity and high capacity and a further one with high affinity and low capacity. The second is similar to the GnRH receptor found in pituitary gonadrotrophs (1-3). The low-affinity binding site is similar to that found in human placenta and corpus luteum and is unable to discriminate between $\mathrm{GnRH}$ agonists and superactive GnRH agonists (4). In addition, the low-affinity GnRH receptor is only 
activated at high concentrations of GnRH agonists, whereas the high-affinity GnRH receptor is fully activated at low levels of GnRH agonists.

Expression and sequence analysis of the $\mathrm{GnRH}$ receptor found in human pituitary gonadotrophs were first demonstrated in 1992 (5). Due to these findings, intensive research was carried out, which lead to the demonstration of high-affinity $\mathrm{GnRH}$ receptors in ovarian and endometrial cancer cell lines and in about $80 \%$ of their respective primary tumors (5-8). High-affinity/low-capacity-binding sites, strongly related to the pituitary $\mathrm{GnRH}$ receptor, were found in specimens of ovarian and endometrial cancers and cell lines, which express mRNA for the GnRH receptor known from pituitary gonadotrophs (6, 7, 9-13). Kakar et al. (14) confirmed that the DNA sequence of $\mathrm{GnRH}$ receptors in human breast and ovarian cancers is identical to that within the pituitary. Harris et al. (15) reported on GnRH mRNA expression in two human breast cancer cell lines. About $50-64 \%$ of human breast cancers have high-affinity GnRH receptors, according to various studies (16-19). A more recent study reported that $\mathrm{GnRH}$ receptor expression was detected in $67 \%$ of hyperplasia cases (4 out of 6 ), in $100 \%$ of benign fibroadenoma cases ( 3 out of 3), in $100 \%$ of carcinoma in situ cases ( 4 out of 4 ), and in $71 \%$ cases of malignant breast cancers (22 out of 31) (20). The therapeutic options today are incredibly limited in particular for triple-negative breast cancers (TNBCs), which do not exhibit either the estrogen receptor $\alpha(E R \alpha)$ or the progesterone receptor and do not overexpress the HER2-neu gene. It has been shown that $74 \%$ of TNBCs $(n=42)$ have $\mathrm{GnRH}$ receptor expression (21). In another study, GnRH receptors were found in all analyzed TNBCs $(n=16)(22)$. Since breast, ovarian, and endometrial cancers express both $\mathrm{GnRH}$ and its receptor, it appears plausible to consider that there may be a regulative system locally based on GnRH in many of these tumors. This also applies to prostate cancer cells (23-25). In addition, expression of $\mathrm{GnRH}$ receptor has also been found in some cancers of non-reproductive tissues, such as cancers of the urinary bladder, pancreatic cancers, and glioblastoma in addition to that found in breast cancers (26-29).

Besides $\mathrm{GnRH}$, another structural version of $\mathrm{GnRH}$ is present in mammals. GnRH-II is completely conserved in its structure from fish to mammals and is different from $\mathrm{GnRH}$ in three amino acids. A specific functional receptor for GnRH-II was identified in different species including non-human primates (30-33). The existence of a GnRH-II receptor in humans is, however, controversial (34). The full-length human GnRH-II receptor is known to be a 7 transmembrane receptor. It has not yet been possible to successfully clone or sequence this receptor (31, 35-37). A functional GnRH-II receptor is likely to be expressed in a variety of splice variants (32). Assuming that a functional GnRH-II receptor is secreted by human tissues, it might be a 5 transmembrane domain receptor, which lacks the transmembrane regions 1 and 2 (32). It was possible to identify mutations of chemokine receptors which are functional 5 transmembrane G-protein-coupled receptors where the $\mathrm{N}$-terminus is linked right to transmembrane domain 3 due to deletion of transmembrane domains 1 and 2 (38). Morgan et al. learned that the human GnRH-II receptor is also present in a number of splice variants (39). It is suspected that the GnRH-II receptor is nonfunctional due to a stop codon within exon $2(35,39)$. A GnRH-II receptor, composed of the three exons required for a complete receptor protein, has recently been cloned from human sperm by Van Biljon et al. (40). This transcript also has a stop codon and a frame shift mutation. While this would suggest that this gene is a transcribed pseudogene, the authors speculate that the GnRH-II receptor in human sperm and testis may have a functional role (40). Evidence for the existence of a functional GnRH-II receptor in human cancers was demonstrated in earlier studies carried out in our laboratory $(35,41,42)$. A GnRH-II receptor-like protein could be detected in cancers of human reproductive organs using an antiserum to the putative human GnRH-II receptor (41). In membrane preparations of these cancer cell lines, a band at approximately $43 \mathrm{kDa}$ was detectable whereas in ovaries obtained from marmoset monkey (Callithrix jacchus) a band at approximately $54 \mathrm{kDa}$ was shown (41). To identify the GnRH-II receptor-like antigen, the photo-affinity-labeling technique was used. Photo chemical reaction of ${ }^{125}$ I-labeled (4-Azidobenzoyl)N-Hydroxysuccinimide-[D-Lys $\left.{ }^{6}\right]-G n R H-I I$ with membrane preparations of human endometrial and ovarian cancer cells yielded a band at approximately $43 \mathrm{kDa}$. Western blot analysis of the same gel using the anti-human GnRH-II receptor antiserum identified this band as GnRH-II receptor-like antigen (41). In competition experiments, GnRH-II agonist [D-Lys $\left.{ }^{6}\right]-G n R H-I I$ showed a strong decrease of ${ }^{125}$ I-labeled (4-Azidobenzoyl)-NHydroxysuccinimide-[D-Lys $\left.{ }^{6}\right]-\mathrm{GnRH}-\mathrm{II}$ binding to its binding site (41). Kim et al., however, has shown that the effects of GnRH and GnRH-II can be reversed by the transfection of shortinterfering RNA to nullify the GnRH receptor gene expression (43). These findings of Kim et al. suggest that the effects of $\mathrm{GnRH}$ and GnRH-II are produced by utilizing the GnRH receptor. Our recent work shows that GnRH-II antagonists bind with the $\mathrm{GnRH}$ receptor in a similar way to how they bind with the GnRH antagonist cetrorelix (19). We were also able to demonstrate that, although GnRH-II antagonists are clearly antagonists at the GnRH receptor, [D-Lys $\left.{ }^{6}\right] \mathrm{GnRH}-\mathrm{II}$ is an agonist at the GnRH receptor (44). Similar results were found for prostate cancer. The GnRH receptor mediates the effects of GnRH-II on prostate cancer cells (45).

\section{ANTIPROLIFERATIVE ACTION OF GnRH IN HUMAN CANCERS}

Dependent upon dose and time, GnRH agonists were found to reduce proliferation of human endometrial, ovarian, and breast cancer cell lines $(1,46)$. Comparable results were found for prostate cancer cell lines (23-25). When tested on most tumor cell lines, $\mathrm{GnRH}$ antagonists act like agonists, which indicate that the dichotomy of GnRH agonist/GnRH antagonist, as described in gonadotrophic cells of the pituitary, is not valid for the GnRH system in tumors of the human being. GnRH antagonists also caused a time- and dose-dependent reduction in cell growth $(1,46)$. In tumor cells, GnRH receptors may be mainly coupling with Gi proteins, which, according to cell lineage, may result in the production of different receptor conformation and signaling 
complexes (47-49). This may help to explain how tumor GnRH receptors have different actions compared with pituitary cells. A reduction in proliferation of human endometrial, ovarian, and breast cancer cells can also be demonstrated with GnRH-II agonists. These effects are significantly greater than those produced by GnRH agonists (35). The reduction in cancer cell growth caused by GnRH or GnRH-II agonists does not appear to be due to induced apoptosis (1). Instead, GnRH and GnRH-II agonists counteract the signaling of growth-factor receptors through activation of a phosphotyrosine phosphatase (PTP). This results in a reduction in cancer cell growth $(47,50,51)$. This is discussed in Section "GnRH Receptor Signal Transduction in Human Cancers."

Antagonistic analogs of GnRH and GnRH-II, in contrast to GnRH and GnRH-II agonists, however, do induce apoptotic cell death in several human cancer cells $(44,52,53)$. In human endometrial and ovarian cancer cells, this occurs due to a dose-dependent loss of mitochondrial membrane potential and induction of caspase- $3(44,52)$. It was possible to confirm these effects in nude mice. The progress of human endometrial and ovarian tumors grown in mice was significantly inhibited by GnRH-II antagonists without causing any apparent side effects $(44,52)$. Apoptotic cell death induced by antagonists of GnRH-II is permitted via the intrinsic cascade through stressactivated mitogen-activated protein kinases (MAPKs) p38- and JNK-induced stimulation of the proapoptotic factor Bax, together with the loss of mitochondrial membrane potential, cytochrome c release, and caspase- 3 activation $(44,52)$.

\section{ANTIMETASTATIC ACTION OF GnRH IN HUMAN CANCERS}

By using coculture to mimic tumor cell invasion, we have forced non-invasive MCF-7 breast cancer cells to behave in an invasive manner resulting in a marked increase in the number of cells undergoing epithelial-mesenchymal transition (EMT) (54-57). By prolonged mammosphere culture, we have made a mesenchymal transformed MCF-7 cell line (MCF-7-EMT), which as opposed to wild-type MCF-7 cells, exhibits a significant increase in invasive behavior both in vitro and in vivo as well as increased expression of EMT-related genes (55). When non-invasive wildtype MCF-7 breast cancer cells were cocultured with human primary osteoblasts or osteoblast-like cell line MG63, the invasion of tumor cells through an artificial basement membrane was dramatically increased (54). Treatment with $\mathrm{GnRH}$ analogs significantly reduced the capability to invade through the basement membrane and to migrate in response to the cellular stimulus (54). GnRH analogs exhibited comparable antimetastatic effects in prostate cancer cells (58).

Approximately $10-15 \%$ of breast cancers are TNBCs, which do not have estrogen receptor $\alpha$ and progesterone receptors and show not an overexpression of HER2-neu (59-61). TNBCs are believed very aggressive and have a poor prognosis. The most frequent site for metastasis formation in breast cancers is bone, followed by the lungs and liver (62). Development of bone metastasis by MDA-MB-435 TNBC cells grown in the mammary glands of nude mice was significantly inhibited by treatment with $\mathrm{GnRH}$ analogs. GnRH analogs also significantly inhibited bone metastasis formation from circulating MDA-MB-231 TNBC cells, which were injected intracardially (63). This indicates that $\mathrm{GnRH}$ analogs may have an influence on the biology of circulating breast cancer cells as well as influencing the first steps of breast cancer metastasis including EMT, migration, and invasion as was already known from in vitro data (54).

The S100 calcium-binding protein A4 (S100A4) and the cysteine-rich angiogenic inducer 61 (CYR61, CCN1) promote cancer cell motility and thus play important roles in EMT, invasion, and metastasis (64-68). Highly invasive MDA-MB-231 breast cancer cells exhibit high expression of both genes (20). An increased CYR61 level correlates with a poor prognosis, poor lymph node status, and metastatic propagation $(69,70)$. Jenkinson et al. showed that S100A4 has a clear influence on the invasiveness of breast cancer cells (71). Breast cancer cells with S100A4 overexpression were shown to be markedly more invasive than the non-transfected controls. High levels of S100A4 and CYR61 were found in biopsy specimens of malignant human breast cancers, whereas in carcinoma, in situ, the expression levels were much lower. No expression of S100A4 and CYR61 was detectable in normal breast tissues and benign fibroadenoma (20). MCF-7 cells are non-invasive and show very low levels of S100A4 and CYR61 expression (20). Invasion of cells and levels of S100A4 and CYR61 expression in MCF-7 cells was markedly increased after mesenchymal transition (MCF-7-EMT) (20). The increase in invasive behavior could be reduced by anti-S100A4 and anti-CYR61 antibodies (20). The use of anti-S100A4 and anti-CYR61 antibodies also reduced invasive behavior in naturally aggressive MDA-MB-231 cells (20). Treatment of mesenchymal transformed MCF-7-EMT and naturally highly invasive MDA-MB-231 cells with a GnRH agonist resulted not only in a significant decrease of invasion but also a reduced expression of S100A4 and CYR61 (20). The neutralization of CYR61 resulted in inhibition of breast cancer metastasis in vivo (72). The precise mechanisms remain unclear and are part of our current research. However, the use of GnRH agonists or similar treatments to block S100A4 and CYR61 should be further explored as they may have new antimetastatic therapeutic potential.

\section{GnRH RECEPTOR SIGNAL TRANSDUCTION IN HUMAN CANCERS}

\section{Interaction of GnRH Receptor and Growth Factor Receptor Signaling}

Over the last two decades, the signal transduction mechanisms affecting the growth inhibiting actions of GnRH analogs in cancer cells of the breast, ovary, and endometrium have been discussed (Figure 1). The GnRH receptor signal transduction in human malignant tumors is different from that found in gonadotrophic cells in the pituitary, where $\mathrm{GnRH}$ receptors bind to G-protein $\alpha q$ and induce activation of phospholipase C (PLC), protein kinase $\mathrm{C}(\mathrm{PKC})$, and adenylyl cyclase (AC) (1). The signal transduction mechanisms activated by $\mathrm{GnRH}$ in gonadotrophic 


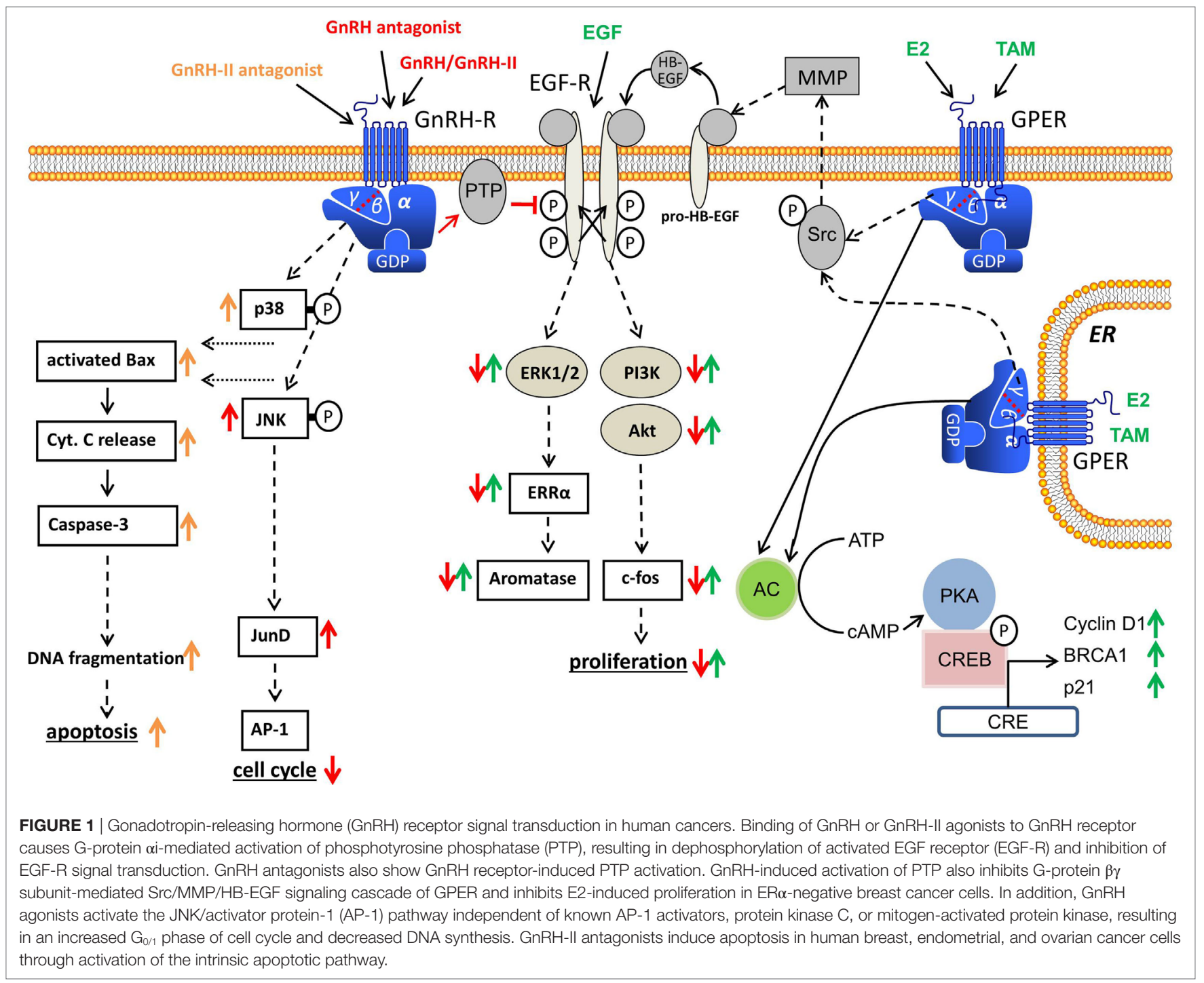

cells of the pituitary were not turned on by GnRH agonists in cancers of the ovary, endometrium, and breast even though activation of PLC, PKC, and AC in cells of these cancers by pharmacological stimulation was clearly shown $(23,47)$. The cancer GnRH receptor binds to G-protein $\alpha$ i after ligand binding and induces activation of a PTP $(23,47,73-76)$. The EGF receptors (EGF-Rs) are dephosphorylated by the PTP (47). Because of this, mitogenic signal transduction, caused by EGF-R activation, is prevented, which leads to the downregulation of EGF-permitted activation of MAPK (23), c-fos expression (51), and EGF-induced proliferation (77). These findings agree with other reports of $\mathrm{GnRH}$ analogs reducing the expression of growth factor receptors (78-80) and/or growth factor-induced tyrosine kinase activity $(23,73,74,76,79,81-83)$. The explanation for the dissimilarities of GnRH receptor signal transduction between gonadotrophic cells of the pituitary and cancer cells is still unclear, as we were unable to identify mutations or splice variations in the cancer cell GnRH receptor, which can have explained the phenomenon (47).
The effects of $\mathrm{GnRH}$ are not confined to mitogenic signal transduction of growth factor receptors. GnRH agonists stimulate activator protein-1 (AP-1) activity via G-protein $\alpha$ in human ovarian and endometrial cancer cells. In addition, GnRH agonists also activate JNK, which is a known trigger of AP-1 (84). In earlier research, it was demonstrated that $\mathrm{GnRH}$ agonists do not induce PLC and PKC in endometrial and ovarian cancer cells (23). GnRH agonists have also been found to inhibit mitogen-activated protein kinase (MAPK, ERK) activity caused by growth factors (23). Activation of the JNK/AP-1 signaling caused by GnRH in endometrial cancer cells is, therefore, independent of the AP-1 activators, PKC, or MAPK (ERK). Yamauchi et al. demonstrated that JNK is involved in the downregulation of cell proliferation, which is caused by the $\alpha 1 \mathrm{~B}$-adrenergic receptor in human embryonic kidney cells (85). In an analysis in rats, it was suggested that $c$-jun mRNA suppression and endometrial epithelial cell growth may be linked (86). Cytokines show inhibitory action on cell growth in UT-OC-3 ovarian cancer cells and activate $\mathrm{AP}-1$ and NFKB (87). As the JNK/c-jun signaling is activated by 
antiproliferative $\mathrm{GnRH}$ agonists and JNK/c-jun was also found to be integrated in reducing cell growth in distinct systems, it seems plausible to consider whether the JNK/c-jun signaling is involved in the inhibitory effect of the $\mathrm{GnRH}$ agonists. We have also shown that $\mathrm{GnRH}$ agonists cause JunD-DNA binding, which results in decreased cell proliferation shown by an increased $G_{0 / 1}$ phase of cell cycle and reduced DNA synthesis (88).

\section{Interaction of GnRH Receptor and Estrogen Receptor Signaling}

Different studies have shown that estrogen receptor $\alpha(E R \alpha)$ mediates $17 \beta$-estradiol (E2)-activated expression of c-fos, which is induced as an immediate early response gene in ER $\alpha$-positive breast cancer cell lines (89-96). ER $\alpha$ activates the serum response element (SRE) in MCF-7 breast cancer cells via MAPK-dependent Elk-1 phosphorylation $(97,98)$. Duan et al. have shown that SRE in breast cancer cells is activated through the Ras/MAPK cascade by both E2 (ER $\alpha$-dependent) and growth factors (ER $\alpha$ independent) (97).

Because GnRH agonists antagonize EGF-induced cell growth and $\mathrm{c}$-fos gene expression through the Ras/MAPK pathway, we have analyzed whether E2-induced activation of SRE and expression of c-fos in ER $\alpha$-positive human breast, endometrial, and ovarian tumor cells is also inhibited by $\mathrm{GnRH}$ agonists and whether $\mathrm{GnRH}$ reduces E2-induced cell proliferation (1). Dormant ER $\alpha$-positive/ER $\beta$-positive breast, endometrial, and ovarian tumor cell lines were stimulated to multiply by treatment with $\mathrm{E} 2$ but $\mathrm{ER} \alpha$-negative/ER $\beta$-positive cell lines were unaffected. This action was time- and dose-dependent inhibited by co-treatment with GnRH agonists (99). We were also able to show that in $\mathrm{ER} \alpha$-positive/ER $\beta$-positive cell lines, E2 activates the SRE and the expression of c-fos. These effects were antagonized by GnRH agonists (99). GnRH agonists did not affect the activation of the estrogen response element caused by E2. Transcriptional SRE activation by E2 is due to activation, by $\mathrm{ER} \alpha$, of the MAPK pathway. GnRH blocks this pathway, which results in a decrease of activated SRE caused by E2 and, in consequence, a decrease in E2-mediated expression of c-fos. This causes a reduction in the cancer cell proliferation caused by E2 (99). PTP activation caused by GnRH also inhibits G-protein $\beta \gamma$ subunit-mediated Src/MMP/HB-EGF signaling cascade of G-protein-coupled estrogen receptor 1 (GPER, GPR-30), which is a membrane-bound receptor for estrogens, which plays an important role in breast cancers, which do not show expression of estrogen receptor $\alpha(E R \alpha)(100-103)$. Because of the inhibition of GPER signaling, cancer cell proliferation, due to E2, in ER $\alpha$-negative breast cancer cells was prevented (100-102).

Recently, we demonstrated that human breast cancer cells are resensitized by $\mathrm{GnRH}$ analogs to the estrogen antagonist 4OH-Tamoxifen (104). We have developed sublines of $4 \mathrm{OH}-$ Tamoxifen resistant cell lines and compared the expression levels of ER, Her-2, EGF-R, and GnRH receptor in the wild-type and the resistant cell lines. We identified slightly decreased expression of GnRH receptors and increased levels of EGF-R in the developed sublines (104). Apoptotic cell death induced by $4 \mathrm{OH}$-Tamoxifen in wild-type MCF-7 and T47D cells was unaffected by $\mathrm{GnRH}$ analogs, but, when the resistant sublines were pretreated with analogs of $\mathrm{GnRH}$, sensitivity for $4 \mathrm{OH}$-Tamoxifen was completely restored in these cells (99). Analogs of GnRH counteract EGF-dependent growth and probably interrupt the change in growth regulation, from being estrogen dependent to being EGF dependent, which ocurrs after acquiring secondary resistance to $4 \mathrm{OH}$-Tamoxifen. This interruption of EGF-R signaling resensitized the resistant cell lines for a therapy using 4OH-Tamoxifen (104).

\section{GnRH RECEPTOR AS TARGET FOR CANCER THERAPY}

Apart from pituitary cells and reproductive organs, most other tissues and hematopoietic stem cells do not show expression of the GnRH receptor (Figure 2). The reproductive organs, ovaries, fallopian tubes, and uterus are regularly eliminated during surgery of ovarian or endometrial cancer (105). These receptors could, therefore, be used to deliver a targeted therapy with improved antitumor effects and reduced side effects. Cytotoxic $\mathrm{GnRH}$ agonists, in which a cytotoxic substance is covalently coupled to a GnRH agonist, have been developed (106). These $\mathrm{GnRH}$ analogs, which are covalently bound to a cytotoxic agent couple specifically to $\mathrm{GnRH}$ receptors with their peptide fraction and operate as chemotherapeutic drug after internalization of the receptor-ligand complex (106). Thus, these cytotoxic GnRH analogs selectively attack only cells that have membrane GnRH receptors and cause fewer side effects than not conjugated cytotoxic substances (106). We demonstrated that such a cytotoxic GnRH agonist, Zoptarelin Doxorubicin (AEZS-108, AN-152), in which doxorubicin is covalently coupled to the $\mathrm{GnRH}$ analog $\left[\mathrm{D}-\mathrm{Lys}^{6}\right] \mathrm{GnRH}$, is selectively accumulated in the nucleus of human GnRH receptor-positive breast, ovarian, and endometrial cancer cell lines. The uptake of Zoptarelin Doxorubicin could be competitively blocked by an excess of another GnRH agonist. No intracellular Zoptarelin Doxorubicin could be found in tumor cell lines that do not have membrane GnRH receptors (107). Zoptarelin Doxorubicin was more potent than doxorubicin in inhibition of cell growth, in vitro, in most GnRH receptorpositive cancer cell lines. These results indicated that Zoptarelin Doxorubicin had a selective receptor-mediated effect on GnRH receptor-positive cancer cell lines and inspired us to analyze the effectiveness of Zoptarelin Doxorubicin in vivo (105). In testing on experimental cancers in nude mice, Zoptarelin Doxorubicin was less toxic than unbound Doxorobicin and more effective in decreasing the growth of $\mathrm{GnRH}$ receptor-positive tumors $(105,108)$. This is thought to be due to the receptor-mediated admission of Zoptarelin Doxorubicin and the reduced causation of multidrug resistance $(109,110)$. Clinical trials of Zoptarelin Doxorubicin were planned as it appears that the drug allows a more effective and less toxic targeted chemotherapy for GnRH receptor-positive cancers. In a dose escalation and pharmacokinetic trial, Zoptarelin Doxorubicin was used by women with $\mathrm{GnRH}$ receptor-positive cancers. The maximum tolerated dose in the absence of supportive medication was found to be $267 \mathrm{mg} / \mathrm{m}^{2}$. This dose was recommended as the starting dose for therapeutic 


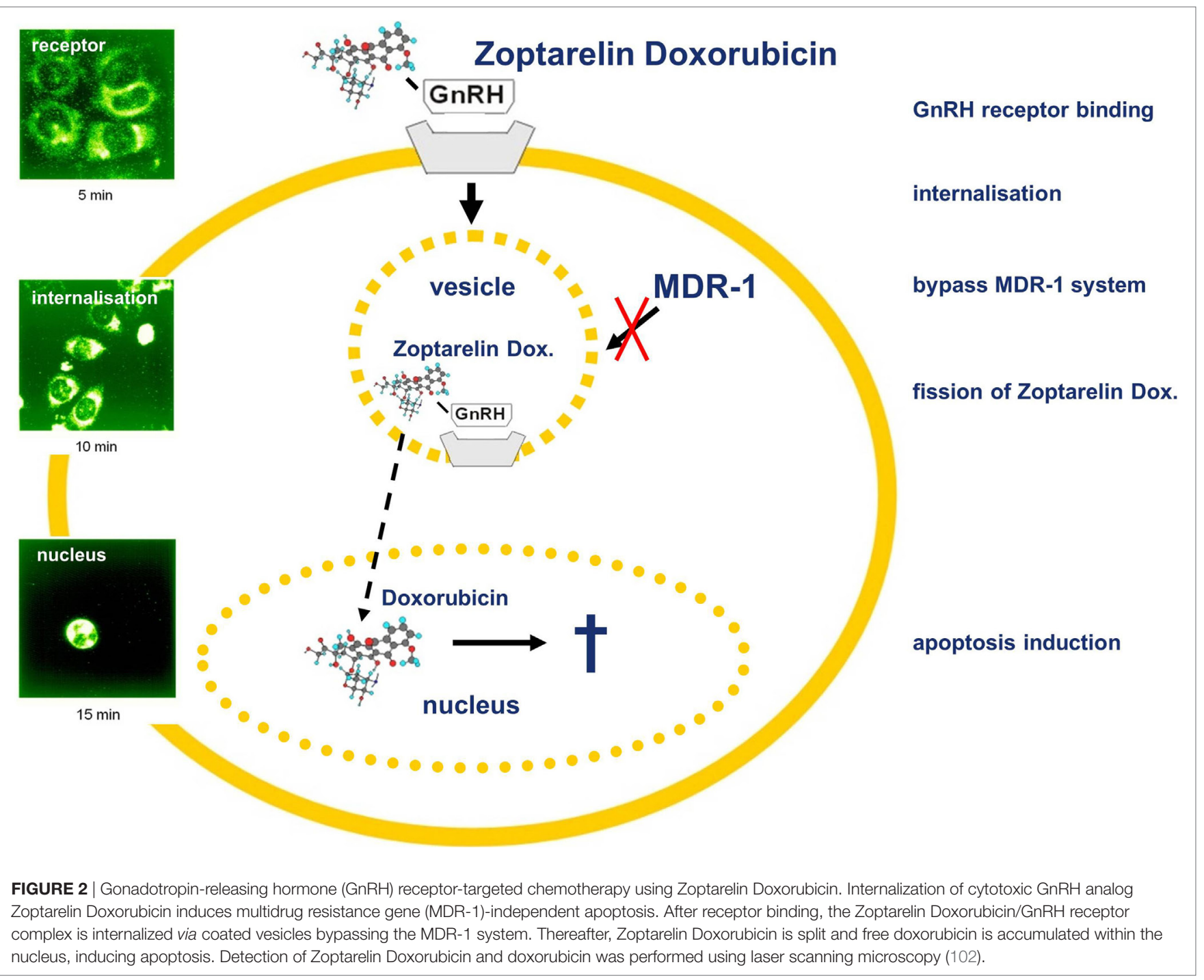

phase II trials (111). It has also been shown, in vitro, that Zoptarelin Doxorubicin is an effective therapeutic option in TNBC where there is a high percentage of $\mathrm{GnRH}$ receptor-positive cancers (21). Other types of tumors were found to be suitable for treatment with Zoptarelin Doxorubicin. Thirty-two percent of pancreatic cancers express $\mathrm{GnRH}$ receptors (28). We demonstrated that treatment of GnRH receptor-positive MiaPaCa-2 and Panc-1 human pancreatic cancer cells with Zoptarelin Doxorubicin resulted in apoptosis in vitro. The antitumor effects could be also demonstrated in nude mice (28). In 2014, the first data from a multicenter phase II trial were published demonstrating that Zoptarelin Doxorubicin proved to be effective and of low toxicity in women with advanced or recurrent $\mathrm{GnRH}$ receptor-positive endometrial cancer (112). A second multicenter phase II trial confirmed that Zoptarelin Doxorubicin is an effective and safe compound for the treatment of women with platinum refractory or resistant ovarian cancers (113). Zoptarelin Doxorubicin is currently in a phase III clinical trial on patients with ovarian or endometrial cancer.

\section{CONCLUSION}

Gonadotropin-releasing hormone plays an important role in the control of mammalian reproduction. In addition to this well-documented classic hypophysiotropic action, GnRH might have a role as a modulator of cell growth and metastasis in a number of human malignant tumors, including cancers of the breast, ovary, endometrium, and prostate. In addition, $\mathrm{GnRH}$ receptors expressed in many tumor types provide suitable targets for the therapy with $\mathrm{GnRH}$ analogs.

\section{AUTHOR CONTRIBUTIONS}

Both authors participated in drafting the article.

\section{ACKNOWLEDGMENTS}

We acknowledge the support by the Open Access Publication Funds of the Göttingen University. 


\section{REFERENCES}

1. Grundker C, Gunthert AR, Westphalen S, Emons G. Biology of the gonadotropin-releasing hormone system in gynecological cancers. Eur J Endocrinol (2002) 146:1-14. doi:10.1530/eje.0.1460001

2. Emons G, Schally AV. The use of luteinizing hormone releasing hormone agonists and antagonists in gynaecological cancers. Hum Reprod (1994) 9:1364-79. doi:10.1093/oxfordjournals.humrep.a138714

3. Loop SM, Gorder CA, Lewis SM, Saiers JH, Drivdahl RH, Ostenson RC. Growth inhibition of human prostate tumor cells by an agonist of gonadotrophin-releasing hormone. Prostate (1995) 26:179-88. doi:10.1002/ pros. 2990260403

4. Eidne KA, Flanagan CA, Harris NS, Millar RP. Gonadotropin-releasing hormone (GnRH)-binding sites in human breast cancer cell lines and inhibitory effects of GnRH antagonists. J Clin Endocrinol Metab (1987) 64:425-32. doi:10.1210/jcem-64-3-425

5. Kakar SS, Musgrove LC, Devor DC, Sellers JC, Neill JD. Cloning, sequencing, and expression of human gonadotropin releasing hormone (GnRH) receptor. Biochem Biophys Res Commun (1992) 189:289-95. doi:10.1016/0006-291X(92)91556-6

6. Imai A, Ohno T, Iida K, Fuseya T, Furui T, Tamaya T. Gonadotropin-releasing hormone receptor in gynecologic tumors. Frequent expression in adenocarcinoma histologic types. Cancer (1994) 74:2555-61. doi:10.1002/10970142(19941101)74:9<2555::AID-CNCR2820740925>3.0.CO;2-X

7. Imai A, Ohno T, Iida K, Fuseya T, Furui T, Tamaya T. Presence of gonadotropin-releasing hormone receptor and its messenger ribonucleic acid in endometrial carcinoma and endometrium. Gynecol Oncol (1994) 55:144-8. doi:10.1006/gyno.1994.1264

8. Imai A, Ohno T, Ohsuye K, Tamaya T. Expression of gonadotropin-releasing hormone receptor in human epithelial ovarian carcinoma. Ann Clin Biochem (1994) 31(Pt 6):550-5. doi:10.1177/000456329403100111

9. Irmer G, Burger C, Muller R, Ortmann O, Peter U, Kakar SS, et al. Expression of the messenger RNAs for luteinizing hormone-releasing hormone (LHRH) and its receptor in human ovarian epithelial carcinoma. Cancer Res (1995) 55:817-22.

10. Emons G, Ortmann O, Becker M, Irmer G, Springer B, Laun R, et al. High affinity binding and direct antiproliferative effects of LHRH analogues in human ovarian cancer cell lines. Cancer Res (1993) 53:5439-46.

11. Emons G, Schroder B, Ortmann O, Westphalen S, Schulz KD, Schally AV. High affinity binding and direct antiproliferative effects of luteinizing hormone-releasing hormone analogs in human endometrial cancer cell lines. J Clin Endocrinol Metab (1993) 77:1458-64. doi:10.1210/jc.77.6.1458

12. Ohno T, Imai A, Furui $\mathrm{T}$, Takahashi $\mathrm{K}$, Tamaya $\mathrm{T}$. Presence of gonadotropin-releasing hormone and its messenger ribonucleic acid in human ovarian epithelial carcinoma. Am J Obstet Gynecol (1993) 169:605-10. doi:10.1016/0002-9378(93)90630-2

13. Irmer G, Burger C, Ortmann O, Schulz KD, Emons G. Expression of luteinizing hormone releasing hormone and its mRNA in human endometrial cancer cell lines. J Clin Endocrinol Metab (1994) 79:916-9. doi:10.1210/ jc.79.3.916

14. Kakar SS, Grizzle WE, Neill JD. The nucleotide sequences of human GnRH receptors in breast and ovarian tumors are identical with that found in pituitary. Mol Cell Endocrinol (1994) 106:145-9. doi:10.1016/0303-7207 (94)90196-1

15. Harris N, Dutlow C, Eidne K, Dong KW, Roberts J, Millar R. Gonadotropinreleasing hormone gene expression in MDA-MB-231 and ZR-75-1 breast carcinoma cell lines. Cancer Res (1991) 51:2577-81.

16. Fekete M, Wittliff JL, Schally AV. Characteristics and distribution of receptors for [D-TRP6]-luteinizing hormone-releasing hormone, somatostatin, epidermal growth factor, and sex steroids in 500 biopsy samples of human breast cancer. J Clin Lab Anal (1989) 3:137-47. doi:10.1002/jcla. 1860030302

17. Baumann KH, Kiesel L, Kaufmann M, Bastert G, Runnebaum B. Characterization of binding sites for a GnRH-agonist (buserelin) in human breast cancer biopsies and their distribution in relation to tumor parameters. Breast Cancer Res Treat (1993) 25:37-46. doi:10.1007/BF00662399

18. Moriya T, Suzuki T, Pilichowska M, Ariga N, Kimura N, Ouchi N, et al. Immunohistochemical expression of gonadotropin releasing hormone receptor in human breast carcinoma. Pathol Int (2001) 51:333-7. doi:10.1046/j.1440-1827.2001.01210.x

19. Mangia A, Tommasi S, Reshkin SJ, Simone G, Stea B, Schittulli F, et al. Gonadotropin releasing hormone receptor expression in primary breast cancer: comparison of immunohistochemical, radioligand and Western blot analyses. Oncol Rep (2002) 9:1127-32. doi:10.3892/or.9.5.1127

20. Grundker C, Bauerschmitz G, Schubert A, Emons G. Invasion and increased expression of S100A4 and CYR61 in mesenchymal transformed breast cancer cells is downregulated by GnRH. Int J Oncol (2016) 48(6):2713-21. doi:10.3892/ijo.2016.3491

21. Fost C, Duwe F, Hellriegel M, Schweyer S, Emons G, Grundker C. Targeted chemotherapy for triple-negative breast cancers via LHRH receptor. Oncol Rep (2011) 25(5):1481-7. doi:10.3892/or.2011.1188

22. Buchholz S, Seitz S, Schally AV, Engel JB, Rick FG, Szalontay L, et al. Triplenegative breast cancers express receptors for luteinizing hormone-releasing hormone (LHRH) and respond to LHRH antagonist cetrorelix with growth inhibition. Int J Oncol (2009) 35:789-96. doi:10.3892/ijo_00000391

23. Dondi D, Limonta P, Moretti RM, Marelli MM, Garattini E, Motta M. Antiproliferative effects of luteinizing hormone-releasing hormone (LHRH) agonists on human androgen-independent prostate cancer cell line DU 145: evidence for an autocrine-inhibitory LHRH loop. Cancer Res (1994) 54:4091-5.

24. Limonta P, Dondi D, Moretti RM, Maggi R, Motta M. Antiproliferative effects of luteinizing hormone-releasing hormone agonists on the human prostatic cancer cell line LNCaP. J Clin Endocrinol Metab (1992) 75:207-12. doi:10.1210/jcem.75.1.1320049

25. Limonta P, Moretti RM, Dondi D, Marelli MM, Motta M. Androgendependent prostatic tumors: biosynthesis and possible actions of LHRH. J Steroid Biochem Mol Biol (1994) 49:347-50. doi:10.1016/0960-0760(94) 90278-X

26. Szepeshazi K, Schally AV, Keller G, Block NL, Benten D, Halmos G, et al. Receptor-targeted therapy of human experimental urinary bladder cancers with cytotoxic LH-RH analog AN-152 [AEZS-108]. Oncotarget (2012) 3:686-99. doi:10.18632/oncotarget.546

27. Fekete M, Zalatnai A, Comaru-Schally AM, Schally AV. Membrane receptors for peptides in experimental and human pancreatic cancers. Pancreas (1989) 4:521-8. doi:10.1097/00006676-198910000-00001

28. Grundker C, Ernst J, Reutter MD, Ghadimi BM, Emons G. Effective targeted chemotherapy using AEZS-108 (AN-152) for LHRH receptorpositive pancreatic cancers. Oncol Rep (2011) 26:629-35. doi:10.3892/or. 2011.1340

29. Montagnani Marelli M, Moretti RM, Mai S, Muller O, Van Groeninghen JC, Limonta P. Novel insights into $\mathrm{GnRH}$ receptor activity: role in the control of human glioblastoma cell proliferation. Oncol Rep (2009) 21:1277-82. doi:10.3892/or_00000351

30. Millar R, Lowe S, Conklin D, Pawson A, Maudsley S, Troskie B, et al. A novel mammalian receptor for the evolutionarily conserved type II GnRH. Proc Natl Acad Sci U S A (2001) 98:9636-41. doi:10.1073/pnas. 141048498

31. Neill JD, Duck LW, Sellers JC, Musgrove LC. A gonadotropin-releasing hormone $(\mathrm{GnRH})$ receptor specific for GnRH II in primates. Biochem Biophys Res Commun (2001) 282:1012-8. doi:10.1006/bbrc.2001.4678

32. Neill JD, Musgrove LC, Duck LW. Newly recognized GnRH receptors: function and relative role. Trends Endocrinol Metab (2004) 15:383-92. doi:10.1016/S1043-2760(04)00186-9

33. Stewart AJ, Katz AA, Millar RP, Morgan K. Retention and silencing of prepro-GnRH-II and type II GnRH receptor genes in mammals. Neuroendocrinology (2009) 90:416-32. doi:10.1159/000233303

34. Grundker C, Fost C, Fister S, Nolte N, Gunthert AR, Emons G. Gonadotropinreleasing hormone type II antagonist induces apoptosis in MCF-7 and triple-negative MDA-MB-231 human breast cancer cells in vitro and in vivo. Breast Cancer Res (2010) 12:R49. doi:10.1186/bcr2606

35. Grundker C, Gunthert AR, Millar RP, Emons G. Expression of gonadotropinreleasing hormone II (GnRH-II) receptor in human endometrial and ovarian cancer cells and effects of GnRH-II on tumor cell proliferation. J Clin Endocrinol Metab (2002) 87:1427-30. doi:10.1210/jcem.87.3.8437

36. Millar RP. GnRH II and type II GnRH receptors. Trends Endocrinol Metab (2003) 14:35-43. doi:10.1016/S1043-2760(02)00016-4 
37. Millar R, Conklin D, Lofton-Day C, Hutchinson E, Troskie B, Illing N, et al. A novel human $\mathrm{GnRH}$ receptor homolog gene: abundant and wide tissue distribution of the antisense transcript. J Endocrinol (1999) 162:117-26. doi:10.1677/joe.0.1620117

38. Ling K, Wang P, Zhao J, Wu YL, Cheng ZJ, Wu GX, et al. Five-transmembrane domains appear sufficient for a $G$ protein-coupled receptor: functional five-transmembrane domain chemokine receptors. Proc Natl Acad Sci U S A (1999) 96:7922-7. doi:10.1073/pnas.96.14.7922

39. Morgan K, Conklin D, Pawson AJ, Sellar R, Ott TR, Millar RP. A transcriptionally active human type II gonadotropin-releasing hormone receptor gene homolog overlaps two genes in the antisense orientation on chromosome 1q.12. Endocrinology (2003) 144:423-36. doi:10.1210/en.2002-220622

40. van Biljon W, Wykes S, Scherer S, Krawetz SA, Hapgood J. Type II gonadotropin-releasing hormone receptor transcripts in human sperm. Biol Reprod (2002) 67:1741-9. doi:10.1095/biolreprod.101.002808

41. Eicke N, Gunthert AR, Viereck V, Siebold D, Behe M, Becker T, et al. GnRH-II receptor-like antigenicity in human placenta and in cancers of the human reproductive organs. Eur J Endocrinol (2005) 153:605-12. doi:10.1530/ eje. 1.02005

42. Grundker C, Schlotawa L, Viereck V, Eicke N, Horst A, Kairies B, et al. Antiproliferative effects of the GnRH antagonist cetrorelix and of GnRH-II on human endometrial and ovarian cancer cells are not mediated through the GnRH type I receptor. Eur J Endocrinol (2004) 151:141-9. doi:10.1530/ eje.0.1510141

43. Kim KY, Choi KC, Auersperg N, Leung PC. Mechanism of gonadotropinreleasing hormone (GnRH)-I and -II-induced cell growth inhibition in ovarian cancer cells: role of the GnRH-I receptor and protein kinase $\mathrm{C}$ pathway. Endocr Relat Cancer (2006) 13:211-20. doi:10.1677/erc.1.01033

44. Fister S, Gunthert AR, Aicher B, Paulini KW, Emons G, Grundker C. GnRH-II antagonists induce apoptosis in human endometrial, ovarian, and breast cancer cells via activation of stress-induced MAPKs p38 and JNK and proapoptotic protein Bax. Cancer Res (2009) 69:6473-81. doi:10.1158/ 0008-5472.CAN-08-4657

45. Montagnani Marelli M, Moretti RM, Mai S, Januszkiewicz-Caulier J, Motta M, Limonta P. Type I gonadotropin-releasing hormone receptor mediates the antiproliferative effects of GnRH-II on prostate cancer cells. J Clin Endocrinol Metab (2009) 94:1761-7. doi:10.1210/jc.2008-1741

46. Emons G, Grundker C, Gunthert AR, Westphalen S, Kavanagh J, Verschraegen C. GnRH antagonists in the treatment of gynecological and breast cancers. Endocr Relat Cancer (2003) 10:291-9. doi:10.1677/ erc. 0.0100291

47. Grundker C, Volker P, Emons G. Antiproliferative signaling of luteinizing hormone-releasing hormone in human endometrial and ovarian cancer cells through $\mathrm{G}$ protein alpha(I)-mediated activation of phosphotyrosine phosphatase. Endocrinology (2001) 142:2369-80. doi:10.1210/endo. 142.6.8190

48. Limonta P, Moretti RM, Marelli MM, Dondi D, Parenti M, Motta M. The luteinizing hormone-releasing hormone receptor in human prostate cancer cells: messenger ribonucleic acid expression, molecular size, and signal transduction pathway. Endocrinology (1999) 140:5250-6. doi:10.1210/ endo.140.11.7087

49. Dobkin-Bekman M, Naidich M, Pawson AJ, Millar RP, Seger R, Naor Z. Activation of mitogen-activated protein kinase (MAPK) by GnRH is cell-context dependent. Mol Cell Endocrinol (2006) 252:184-90. doi:10.1016/j.mce.2006.03.035

50. Emons G, Muller V, Ortmann O, Schulz KD. Effects of LHRH-analogues on mitogenic signal transduction in cancer cells. J Steroid Biochem Mol Biol (1998) 65:199-206. doi:10.1016/S0960-0760(97)00189-1

51. Grundker C, Volker P, Schulz KD, Emons G. Luteinizing hormone-releasing hormone agonist triptorelin and antagonist cetrorelix inhibit EGF-induced c-fos expression in human gynecological cancers. Gynecol Oncol (2000) 78:194-202. doi:10.1006/gyno.2000.5863

52. Fister S, Gunthert AR, Emons G, Grundker C. Gonadotropin-releasing hormone type II antagonists induce apoptotic cell death in human endometrial and ovarian cancer cells in vitro and in vivo. Cancer Res (2007) 67:1750-6. doi:10.1158/0008-5472.CAN-06-3222

53. Kwon JY, Park KH, Park YN, Cho NH. Effect of cetrorelix acetate on apoptosis and apoptosis regulatory factors in cultured uterine leiomyoma cells. Fertil Steril (2005) 84:1526-8. doi:10.1016/j.fertnstert.2005.06.022
54. von Alten J, Fister S, Schulz H, Viereck V, Frosch KH, Emons G, et al. GnRH analogs reduce invasiveness of human breast cancer cells. Breast Cancer Res Treat (2006) 100:13-21. doi:10.1007/s10549-006-9222-z

55. Ziegler E, Hansen MT, Haase M, Emons G, Grundker C. Generation of MCF-7 cells with aggressive metastatic potential in vitro and in vivo. Breast Cancer Res Treat (2014) 148:269-77. doi:10.1007/s10549-014-3159-4

56. Olbrich T, Ziegler E, Turk G, Schubert A, Emons G, Grundker C. Kisspeptin-10 inhibits bone-directed migration of GPR54-positive breast cancer cells: evidence for a dose-window effect. Gynecol Oncol (2010) 119:571-8. doi:10.1016/j.ygyno.2010.08.018

57. Magliocco A, Egan C. Breast cancer metastasis: advances trough the use of in vitro co-culture model systems. In: Gunduz M, Gunduz E, editors. Breast Cancer - Focusing Tumor Micriinvironment, Stem Cells and Metastasis. Rijeka, Croatia: InTech (2011) 511-30.

58. Dondi D, Festuccia C, Piccolella M, Bologna M, Motta M. GnRH agonists and antagonists decrease the metastatic progression of human prostate cancer cell lines by inhibiting the plasminogen activator system. Oncol Rep (2006) 15:393-400. doi:10.3892/or.15.2.393

59. Kim MJ, Ro JY, Ahn SH, Kim HH, Kim SB, Gong G. Clinicopathologic significance of the basal-like subtype of breast cancer: a comparison with hormone receptor and Her2/neu-overexpressing phenotypes. Hum Pathol (2006) 37:1217-26. doi:10.1016/j.humpath.2006.04.015

60. Nielsen TO, Hsu FD, Jensen K, Cheang M, Karaca G, Hu Z, et al. Immunohistochemical and clinical characterization of the basal-like subtype of invasive breast carcinoma. Clin Cancer Res (2004) 10:5367-74. doi:10.1158/1078-0432.CCR-04-0220

61. Bauer KR, Brown M, Cress RD, Parise CA, Caggiano V. Descriptive analysis of estrogen receptor (ER)-negative, progesterone receptor (PR)-negative, and HER2-negative invasive breast cancer, the so-called triple-negative phenotype: a population-based study from the California cancer Registry. Cancer (2007) 109:1721-8. doi:10.1002/cncr.22618

62. Lacroix M. Significance, detection and markers of disseminated breast cancer cells. Endocr Relat Cancer (2006) 13:1033-67. doi:10.1677/ERC-06-0001

63. Schubert A, Hawighorst T, Emons G, Grundker C. Agonists and antagonists of GnRH-I and -II reduce metastasis formation by triple-negative human breast cancer cells in vivo. Breast Cancer Res Treat (2011) 130:783-90. doi:10.1007/s10549-011-1358-9

64. Grum-Schwensen B, Klingelhofer J, Berg CH, El-Naaman C, Grigorian M, Lukanidin E, et al. Suppression of tumor development and metastasis formation in mice lacking the S100A4(mts1) gene. Cancer Res (2005) 65:3772-80. doi:10.1158/0008-5472.CAN-04-4510

65. Kireeva ML, Mo FE, Yang GP, Lau LF. Cyr61, a product of a growth factor-inducible immediate-early gene, promotes cell proliferation, migration, and adhesion. Mol Cell Biol (1996) 16:1326-34. doi:10.1128/MCB.16.4.1326

66. Mazzucchelli L. Protein S100A4: too long overlooked by pathologists? Am J Pathol (2002) 160:7-13. doi:10.1016/S0002-9440(10)64342-8

67. Mahon PC, Baril P, Bhakta V, Chelala C, Caulee K, Harada T, et al. S100A4 contributes to the suppression of BNIP3 expression, chemoresistance, and inhibition of apoptosis in pancreatic cancer. Cancer Res (2007) 67:6786-95. doi:10.1158/0008-5472.CAN-07-0440

68. Leask A, Abraham DJ. All in the CCN family: essential matricellular signaling modulators emerge from the bunker. J Cell Sci (2006) 119:4803-10. doi: $10.1242 /$ jcs. 03270

69. Jiang WG, Watkins G, Fodstad O, Douglas-Jones A, Mokbel K, Mansel RE. Differential expression of the CCN family members Cyr61, CTGF and Nov in human breast cancer. Endocr Relat Cancer (2004) 11:781-91. doi:10.1677/ erc. 1.00825

70. Xie D, Nakachi K, Wang H, Elashoff R, Koeffler HP. Elevated levels of connective tissue growth factor, WISP-1, and CYR61 in primary breast cancers associated with more advanced features. Cancer Res (2001) 61:8917-23.

71. Jenkinson SR, Barraclough R, West CR, Rudland PS. S100A4 regulates cell motility and invasion in an in vitro model for breast cancer metastasis. Br J Cancer (2004) 90:253-62. doi:10.1038/sj.bjc.6601483

72. Lin J, Huo R, Wang L, Zhou Z, Sun Y, Shen B, et al. A novel anti-Cyr61 antibody inhibits breast cancer growth and metastasis in vivo. Cancer Immunol Immunother (2012) 61:677-87. doi:10.1007/s00262-011-1135-y

73. Lee MT, Liebow C, Kamer AR, Schally AV. Effects of epidermal growth factor and analogues of luteinizing hormone-releasing hormone and somatostatin on phosphorylation and dephosphorylation of tyrosine residues of specific 
protein substrates in various tumors. Proc Natl Acad Sci U S A (1991) 88:1656-60. doi:10.1073/pnas.88.5.1656

74. Furui T, Imai A, Takagi H, Horibe S, Fuseya T, Tamaya T. Phosphotyrosine phosphatase-activity in membranes from endometrial carcinoma. Oncol Rep (1995) 2:1055-7.

75. Imai A, Takagi H, Horibe S, Fuseya $\mathrm{T}$, Tamaya $\mathrm{T}$. Coupling of gonadotropinreleasing hormone receptor to $\mathrm{Gi}$ protein in human reproductive tract tumors. J Clin Endocrinol Metab (1996) 81:3249-53. doi:10.1210/jc.81.9.3249

76. Imai A, Takagi H, Furui T, Horibe S, Fuseya T, Tamaya T. Evidence for coupling of phosphotyrosine phosphatase to gonadotropin-releasing hormone receptor in ovarian carcinoma membrane. Cancer (1996) 77:132-7. doi:10.1002/ (SICI) 1097-0142(19960101)77:1<132::AID-CNCR22>3.0.CO;2-5

77. Miller WR, Scott WN, Morris R, Fraser HM, Sharpe RM. Growth of human breast cancer cells inhibited by a luteinizing hormone-releasing hormone agonist. Nature (1985) 313:231-3. doi:10.1038/313231a0

78. Yano T, Pinski J, Halmos G, Szepeshazi K, Groot K, Schally AV. Inhibition of growth of OV-1063 human epithelial ovarian cancer xenografts in nude mice by treatment with luteinizing hormone-releasing hormone antagonist SB-75. Proc Natl Acad Sci U S A (1994) 91:7090-4. doi:10.1073/pnas.91.15. 7090

79. Moretti RM, Marelli MM, Dondi D, Poletti A, Martini L, Motta M, et al. Luteinizing hormone-releasing hormone agonists interfere with the stimulatory actions of epidermal growth factor in human prostatic cancer cell lines, LNCaP and DU 145. J Clin Endocrinol Metab (1996) 81:3930-7. doi:10.1210/ jc. 81.11 .3930

80. Shirahige Y, Cook C, Pinski J, Halmos G, Nair R, Schally A. Treatment with luteinizing-hormone-releasing hormone antagonist sb-75 decreases levels of epidermal growth-factor receptor and its messenger-RNA in ov-1063 human epithelial ovarian-cancer xenografts in nude-mice. Int J Oncol (1994) 5:1031-5.

81. Keri G, Balogh A, Szoke B, Teplan I, Csuka O. Gonadotropin-releasing hormone analogues inhibit cell proliferation and activate signal transduction pathways in MDA-MB-231 human breast cancer cell line. Tumour Biol (1991) 12:61-7. doi:10.1159/000217689

82. Liebow C, Lee MT, Kamer AR, Schally AV. Regulation of luteinizing hormone-releasing hormone receptor binding by heterologous and autologous receptor-stimulated tyrosine phosphorylation. Proc Natl Acad Sci U S A (1991) 88:2244-8. doi:10.1073/pnas.88.6.2244

83. Hershkovitz E, Marbach M, Bosin E, Levy J, Roberts CT Jr, LeRoith D, et al. Luteinizing hormone-releasing hormone antagonists interfere with autocrine and paracrine growth stimulation of MCF-7 mammary cancer cells by insulin-like growth factors. J Clin Endocrinol Metab (1993) 77:963-8. doi:10.1210/jc.77.4.963

84. Grundker C, Schlotawa L, Viereck V, Emons G. Protein kinase C-independent stimulation of activator protein-1 and c-Jun N-terminal kinase activity in human endometrial cancer cells by the LHRH agonist triptorelin. Eur J Endocrinol (2001) 145:651-8. doi:10.1530/eje.0.1450651

85. Yamauchi J, Itoh H, Shinoura H, Miyamoto Y, Hirasawa A, Kaziro Y, et al. Involvement of c-Jun $\mathrm{N}$-terminal kinase and p38 mitogen-activated protein kinase in alpha1B-adrenergic receptor/Galphaq-induced inhibition of cell proliferation. Biochem Biophys Res Commun (2001) 281:1019-23. doi:10.1006/bbrc.2001.4472

86. Bigsby RM, Li A. Differentially regulated immediate early genes in the rat uterus. Endocrinology (1994) 134:1820-6. doi:10.1210/endo.134.4.8137748

87. Seppanen M, Lin L, Punnonen J, Grenman S, Punnonen R, Vihko KK. Regulation of UT-OC-3 ovarian carcinoma cells by cytokines: inhibitory effects on cell proliferation and activation of transcription factors AP-1 and NF-kappaB. Eur J Endocrinol (2000) 142:393-401. doi:10.1530/eje.0.1420393

88. Gunthert AR, Grundker C, Hollmann K, Emons G. Luteinizing hormonereleasing hormone induces JunD-DNA binding and extends cell cycle in human ovarian cancer cells. Biochem Biophys Res Commun (2002) 294:11-5. doi:10.1016/S0006-291X(02)00427-8

89. Bonapace IM, Addeo R, Altucci L, Cicatiello L, Bifulco M, Laezza C, et al. 17 beta-estradiol overcomes a G1 block induced by HMG-CoA reductase inhibitors and fosters cell cycle progression without inducing ERK-1 and -2 MAP kinases activation. Oncogene (1996) 12:753-63.

90. Doucas V, Spyrou G, Yaniv M. Unregulated expression of c-Jun or c-Fos proteins but not Jun $\mathrm{D}$ inhibits oestrogen receptor activity in human breast cancer derived cells. EMBO J (1991) 10:2237-45.
91. Duan R, Porter W, Safe S. Estrogen-induced c-fos protooncogene expression in MCF-7 human breast cancer cells: role of estrogen receptor Sp1 complex formation. Endocrinology (1998) 139:1981-90. doi:10.1210/endo.139. 4.5870

92. van der Burg B, de Groot RP, Isbrucker L, Kruijer W, de Laat SW. Stimulation of TPA-responsive element activity by a cooperative action of insulin and estrogen in human breast cancer cells. Mol Endocrinol (1990) 4:1720-6. doi:10.1210/mend-4-11-1720

93. van der Burg B, de Groot RP, Isbrucker L, Kruijer W, de Laat SW. Oestrogen directly stimulates growth factor signal transduction pathways in human breast cancer cells. J Steroid Biochem Mol Biol (1991) 40:215-21. doi:10.1016/0960-0760(91)90185-8

94. van der Burg B, van Selm-Miltenburg AJ, de Laat SW, van Zoelen EJ. Direct effects of estrogen on c-fos and c-myc protooncogene expression and cellular proliferation in human breast cancer cells. Mol Cell Endocrinol (1989) 64:223-8. doi:10.1016/0303-7207(89)90149-4

95. Weisz A, Bresciani F. Estrogen regulation of proto-oncogenes coding for nuclear proteins. Crit Rev Oncog (1993) 4:361-88.

96. Wilding G, Lippman ME, Gelmann EP. Effects of steroid hormones and peptide growth factors on protooncogene c-fos expression in human breast cancer cells. Cancer Res (1988) 48:802-5.

97. Duan R, Xie W, Burghardt RC, Safe S. Estrogen receptor-mediated activation of the serum response element in MCF-7 cells through MAPK-dependent phosphorylation of Elk-1. J Biol Chem (2001) 276:11590-8. doi:10.1074/jbc. M005492200

98. Duan R, Xie W, Li X, McDougal A, Safe S. Estrogen regulation of c-fos gene expression through phosphatidylinositol-3-kinase-dependent activation of serum response factor in MCF-7 breast cancer cells. Biochem Biophys Res Commun (2002) 294:384-94. doi:10.1016/S0006-291X(02)00499-0

99. Grundker C, Gunthert AR, Hellriegel M, Emons G. Gonadotropin-releasing hormone (GnRH) agonist triptorelin inhibits estradiol-induced serum response element (SRE) activation and c-fos expression in human endometrial, ovarian and breast cancer cells. Eur J Endocrinol (2004) 151:619-28. doi:10.1530/eje.0.1510619

100. Girgert R, Emons G, Grundker C. Inactivation of GPR30 reduces growth of triple-negative breast cancer cells: possible application in targeted therapy. Breast Cancer Res Treat (2012) 134:199-205. doi:10.1007/s10549-0121968-x

101. Girgert R, Emons G, Grundker C. Inhibition of GPR30 by estriol prevents growth stimulation of triple-negative breast cancer cells by 17beta-estradiol. BMC Cancer (2014) 14:935. doi:10.1186/1471-2407-14-935

102. Girgert R, Emons G, Grundker C. 17beta-estradiol-induced growth of triple-negative breast cancer cells is prevented by the reduction of GPER expression after treatment with gefitinib. Oncol Rep (2017) 37:1212-8. doi:10.3892/or.2016.5306

103. Luttrell LM, Daaka Y, Lefkowitz RJ. Regulation of tyrosine kinase cascades by G-protein-coupled receptors. Curr Opin Cell Biol (1999) 11:177-83. doi:10.1016/S0955-0674(99)80023-4

104. Gunthert AR, Grundker C, Olota A, Lasche J, Eicke N, Emons G. Analogs of GnRH-I and GnRH-II inhibit epidermal growth factor-induced signal transduction and resensitize resistant human breast cancer cells to $4 \mathrm{OH}$-tamoxifen. Eur J Endocrinol (2005) 153:613-25. doi:10.1530/eje.1.01996

105. Grundker C, Volker P, Griesinger F, Ramaswamy A, Nagy A, Schally AV, et al. Antitumor effects of the cytotoxic luteinizing hormone-releasing hormone analog AN-152 on human endometrial and ovarian cancers xenografted into nude mice. Am JObstet Gynecol (2002) 187:528-37. doi:10.1067/ mob.2002.124278

106. Schally AV, Nagy A. Cancer chemotherapy based on targeting of cytotoxic peptide conjugates to their receptors on tumors. Eur JEndocrinol (1999) 141:1-14. doi:10.1530/eje.0.1410001

107. Westphalen S, Kotulla G, Kaiser F, Krauss W, Werning G, Elsasser HP, et al. Receptor mediated antiproliferative effects of the cytotoxic LHRH agonist AN-152 in human ovarian and endometrial cancer cell lines. Int J Oncol (2000) 17:1063-72. doi:10.3892/ijo.17.5.1063

108. Engel JB, Schally AV, Dietl J, Rieger L, Honig A. Targeted therapy of breast and gynecological cancers with cytotoxic analogues of peptide hormones. Mol Pharm (2007) 4:652-8. doi:10.1021/mp0700514

109. Gunthert AR, Grundker C, Bongertz T, Nagy A, Schally AV, Emons G. Induction of apoptosis by AN-152, a cytotoxic analog of luteinizing 
hormone-releasing hormone (LHRH), in LHRH-R positive human breast cancer cells is independent of multidrug resistance-1 (MDR-1) system. Breast Cancer Res Treat (2004) 87:255-64. doi:10.1007/s10549-004-8806-8

110. Gunthert AR, Grundker C, Bongertz T, Schlott T, Nagy A, Schally AV, et al. Internalization of cytotoxic analog $\mathrm{AN}-152$ of luteinizing hormone-releasing hormone induces apoptosis in human endometrial and ovarian cancer cell lines independent of multidrug resistance-1 (MDR-1) system. Am J Obstet Gynecol (2004) 191:1164-72. doi:10.1016/j.ajog.2004.04.020

111. Emons G, Kaufmann M, Gorchev G, Tsekova V, Grundker C, Gunthert AR, et al. Dose escalation and pharmacokinetic study of AEZS-108 (AN-152), an LHRH agonist linked to doxorubicin, in women with LHRH receptor-positive tumors. Gynecol Oncol (2010) 119:457-61. doi:10.1016/j.ygyno.2010.08.003

112. Emons G, Gorchev G, Harter P, Wimberger P, Stahle A, Hanker L, et al. Efficacy and safety of AEZS-108 (LHRH agonist linked to doxorubicin) in women with advanced or recurrent endometrial cancer expressing LHRH receptors: a multicenter phase 2 trial (AGO-GYN5). Int J Gynecol Cancer (2014) 24:260-5. doi:10.1097/IGC.0000000000000044
113. Emons G, Gorchev G, Sehouli J, Wimberger P, Stahle A, Hanker L, et al. Efficacy and safety of AEZS-108 (INN: zoptarelin doxorubicin acetate) an LHRH agonist linked to doxorubicin in women with platinum refractory or resistant ovarian cancer expressing LHRH receptors: a multicenter phase II trial of the ago-study group (AGO GYN 5). Gynecol Oncol (2014) 133:427-32. doi:10.1016/j.ygyno.2014.03.576

Conflict of Interest Statement: The authors declare that the research was conducted in the absence of any commercial or financial relationships that could be construed as a potential conflict of interest.

Copyright (c) 2017 Gründker and Emons. This is an open-access article distributed under the terms of the Creative Commons Attribution License (CC BY). The use, distribution or reproduction in other forums is permitted, provided the original author(s) or licensor are credited and that the original publication in this journal is cited, in accordance with accepted academic practice. No use, distribution or reproduction is permitted which does not comply with these terms. 